89th and 74th parallels. At present, we have provisionally calculated thirteen of these gravitational points. The last points it was impossible to calculate, as the increasing rapidity of the drift towards the end compelled us to carry out all observations much more frequently and to postpone their working up. The difference between our results and the values given for the same points by the international formula is as follows. At the 89th parallel the observations of the force of gravity practically coincided with the theoretical values. From the 88th to the 84th parallel stretches a field of positive anomaly. Here our measurements give a value greater by approximately $60 \mathrm{mgm}$. than was supposed. From the 84th to the 83rd parallel is observed a sharp decline in the measured value. At the 83rd parallel the anomaly already has a negative significance of approximately $-30 \mathrm{mgm}$. Evidently this jump is closely connected with the relief of the bed. Here, as it happens, a rise to the shallow waters at the coasts of Greenland commences.

The object of our magnetic measurements was to elucidate the geographical distribution of the elements of terrestrial magnetism over the course of the drift : inclination, declination and horizontal intensity. For this we made our measurements with the help of a magnetic theodolite. During our stay on the ice floe, we made fifty-five series of determinations of inclinations and horizontal intensity, and thirty-six measurements of declinations. The measurements were taken right up to lat. $84^{\circ} \mathrm{N}$. Farther on, the icefloe began to rotate so rapidly that it was impossible to use the variometers. It became necessary to take more frequent measurements in order, so far as possible, to weaken the effect of the magnetic disturbances. The measurements show that over the entire stretch of our drift there were no considerable magnetic anomalies.

With the setting in of the darkness at the beginning of October, we began to make hourly visual observations of the northern lights, and continued these until February 9.

Meteorological observations were carried out by us four times a day. We measured the temperature of the air, pressure (by two aneroids), humidity (in the summer by psychrometer; from August, during the periods of frosts, by a hair hygrometer of the Kuznetsov type), direction and velocity of the wind. At first all the four daily measurements of wind velocity were carried out by an anemometer. Later, when one of our anemometers went out of action, we used the remaining one only once a day, and the other three times determined the velocity of the wind visually. Up to the middle of October we have an unbroken record of wind velocity taken by the anemograph. The barograph and thermograph kept on functioning the whole time.

The rapid drift of the ice permitted us to spend only four summer months in the region of the cold polar cap, the investigation of which is of so great an interest to meteorology. It can now be said with certitude that the weather in this region is considerably calmer than on the borders of the Arctic Ocean. For example, we never observed any very strong winds there, though we did not find the steady anticyclonic regime supposed to exist in that region. Our observations were communicated to the mainland daily.

The foregoing is a provisional account of the results of our scientific work. Immediately on our return home we shall begin to work up our material, so as to give a complete account of the investigations carried out by our expedition to the North Pole.

\title{
Oil from Coal*
}

THE report of the Sub-committee on Oil from Coal of the Committee of Imperial Defence serves a useful purpose, although nothing new is disclosed. Unless unexpected discoveries of petroleum should result from the exploratory work conducted by oil companies as an outcome of the recent Petroleum Act, Great Britain has only one alternative to importing practically the whole of its oil supplies : that is, the large-scale conversion of coal into oil by hydrogenation or synthesis, processes which are still very costly in both capital and operation. Oil and motor spirit

* Committee of Imperial Defence. Sub-Committee on Oil from Coal : Report (Cmd. 5665). Pp. 71. (Inndon: H.M. Stationery Office, 1938.) 1s. $3 d$. net. are produced in small proportions as by-products from the carbonization industries, but such sources are not capable of indefinite expansion, since their industrial stability is dependent upon adequate markets for the main products-coke of various kinds or gas. They were, however, stimulated by the guaranteed preference at the rate of $4 d$. a gallon for ten years which has operated in favour of home-produced motor spirit since the Act of 1934. Although only $4 d$. per gallon is guaranteed by this Act, the actual preference which has been in operation since 1934 has been $8 d$., but this involves a shortening of the period during which the guarantee is effective. The report recommends 
that the guarantee should be increased to $8 d$. a gallon and remain in operation until 1950, and that it should be extended to include diesel oil used in motor vehicles.

It might be feared that this extension would involve a loss of revenue, but the consumption of oil and motor spirit is increasing so rapidly that any expansion of the various industries producing oil from coal would probably, at most, only provide for the increase, and could take place without reducing the present imports.

The Committee includes in its report a very welcome discussion of the position in time of war, and this probably forms its most valuable contribution. Much confusion has arisen in the past from the statements of parties interested in particular processes, or from well-meaning individuals who have based their deductions on incomplete knowledge. Even should carbonization processes expand to a degree wildly in excess of anything at present appearing commercially practicable, the supplies of motor spirit forthcoming would form only a small fraction of those needed in times of national emergency. The only methods which can be looked to as potential sources of large supplies of oil are hydrogenation and the Fischer or similar synthetic processes, where oil is the main product and is independent of the markets for coke and gas.

At present, only about 7 per cent of the motor spirit consumed in Great Britain is home-produced, and the home production of fuel oil, lubricating oil, etc., is negligible. An enormous expansion, involving the erection of many large plants, with consequent heavy capital expenditure, would thus be required to meet even peace-time demands. If such plants were put into operation, the consequent decrease in imported oil would eventually result in a considerable diminution of our sea transport facilities and make the possibility of import during war much more difficult. Moreover, large oil production plants would be extremely vulnerable to air attacks ; and the man-power and supplies of coal needed for their operation, although an advantage in times of peace, might not be easy to provide when the fighting and munitions supply services were demanding all the men available. An interesting comparison is made between the capital cost of a plant with a yearly output of 150,000 tons of motor spirit (about $£ 8,000,000$ ) and the thirty-two tankers which could be built for the same sum, which, even if making only five voyages yearly, could carry $1,800,000$ tons, or twelve times the output of the hydrogenation plant.

For these and other reasons, the Committee confirms the opinions already formed by those who have studied the subject impartially, that "in general a policy of depending on imported supplies with adequate storage is the most reliable and economical means of providing for an emergency".

Although in general agreement with the remarks of the Committee concerning low-temperature carbonization, the writer thinks it a pity that evidence in this field should have been taken only from the Low Temperature Distillers' Association of Great Britain, Ltd. In a subject which is still so experimental as low-temperature carbonization, an association of this character cannot be altogether representative, for, since it is not likely to welcome newcomers to introduce additional competition, much valuable data must be withheld from it. The Committee has, however, doubtless been in close touch with the Government Departments concerned in the matter.

C. H. Lander.

\section{Archæological Discovery in Britain, 1933-38}

$\mathrm{I}^{\mathrm{N}}$ arranging an exhibition at the Institute of Archæology of the University of London to illustrate the achievement of field archæology in Great Britain and Northern Ireland during the five years 1933-38, the promoters have provided a conspectus of results which is continuous with those of the two exhibitions of a similar character held in 1929 and 1932, the latter in conjunction with the International Congress of Pre- and Protohistoric Sciences, which met in London in that year. The inevitable comparison demonstrates the very considerable advance made by archæological studies in the interval, and its direction.
The most striking feature in such a comparison is the increase in size of the present exhibition. This is not merely a matter of the total of exhibits, but also extends to the number of sites represented. For this the more efficient organization now possible is in part responsible; but unquestionably the decisive factors have been the growing activities of archæologists, and in no small degree an increased and more widely spread interest among a public which is prepared to support archæological excavation, financially and otherwise. For this part credit must be allowed to the Office of Works, which in the exercise of its statutory duties has 